\title{
THE GLACIAL LAKES OF KUMAON, INDIA
}

\author{
By H. B. Saxena \\ (Department of Geology, Muslim University, Aligarh, India)
}

\begin{abstract}
In the Kumaon region of the outer Himalayas there is a chain of lakes which, on the basis of various features, were previously thought to be of tectonic origin. A detailed geological study of this area carried out in June ${ }_{196} \mathrm{I}$ revealed the presence of morainic deposits in the vicinity of the lakes, and it is now considered that they are essentially of glacial origin.

Résumé. Dans la région de Kumaon, en bordure de l'Himalaya, il existe une chaîne de lacs dont l'origine était supposée tectonique sur la base de divers caractères. Une étude géologique détaillée de cette région, effectuée en juin I96r, a révélé la présence de dépôts morainiques au voisinage des lacs qui sont maintenant considérés comme étant d'origine essentiellement glaciaire.

Zusammenfassung. Im Kumaon-Gebiet des äusseren Himalayas liegt eine Kette von Seen, deren Entstehung bisher auf Grund verschiedener Anzeichen für tektonisch gehalten wurde. Eine eingehende geologische Untersuchung dieses Gebietes im Juni 196 I erwies jedoch das Vorhandensein von Moränen-Ablagerungen in der Nachbarschaft der Seen; sie werden deshalb jetzt im wesentlichen für glazialen Ursprungs betrachtet.
\end{abstract}

\section{INTRODUGTION}

In the Kumaon region of the outer Himalayas, there is a chain of about half a dozen lakes south-east of Nainital, district of Uttar Pradesh, in the approximate lat. $29^{\circ} 23^{\prime} \mathrm{N}$. and long. $79^{\circ} 3 \mathrm{I}^{\prime}$ E. (Fig. I). From a geological point of view the most interesting are Bhim Tal, Naukuchiya Tal and Sat Tal. These three lakes are situated in deep valleys and hollows surrounded by hills trending from north-west to south-east and exhibiting an anticlinal structure. The author had an opportunity of visiting this area in June $196 \mathrm{I}$, and made a detailed study of the geology.

\section{Geology of the Area}

In this area there are innumerable simple folds which are generally responsible for shaping the topography. The maximum altitude of the hills is almost $\mathrm{r}, 830 \mathrm{~m}$. above sea-level and they slope gently towards the north-east. The valleys are narrow with the streams running through them cutting deep gorges.

The main rock types in this area are quartzites, phyllites, schists, granites and basic rocks. The quartzites, which are dominant and widely distributed, are generally compact and massive, and in places they are occasionally intercalated with other rock types. Phyllites overlie the quartzites in thin bands and are persistent throughout. A green variety of weathered chlorite-schist occurs at the contact between the granites and the phyllites and quartzites. Dark massive basalts and dolerites are also prominent at some places. Stratigraphically these rocks can be placed in the following order: granites and basic rocks (basalts and dolerites); schists; phyllites; quartzites.

\section{Description of the LAKes}

\section{Bhim Tal}

This is the largest lake of the group, having a roughly triangular shape. It is about $9 \cdot 7 \mathrm{~km}$. east-south-east of Nainital and is surrounded by high hills on the east and west. There are narrow gaps at the corners of this triangle, but the most prominent is the one in the east which exhibits deep cutting and through which a small stream flows. North-east of Bhim Tal the hills are entirely composed of basic rocks (basalts and dolerites); basalts occupy the southern part 


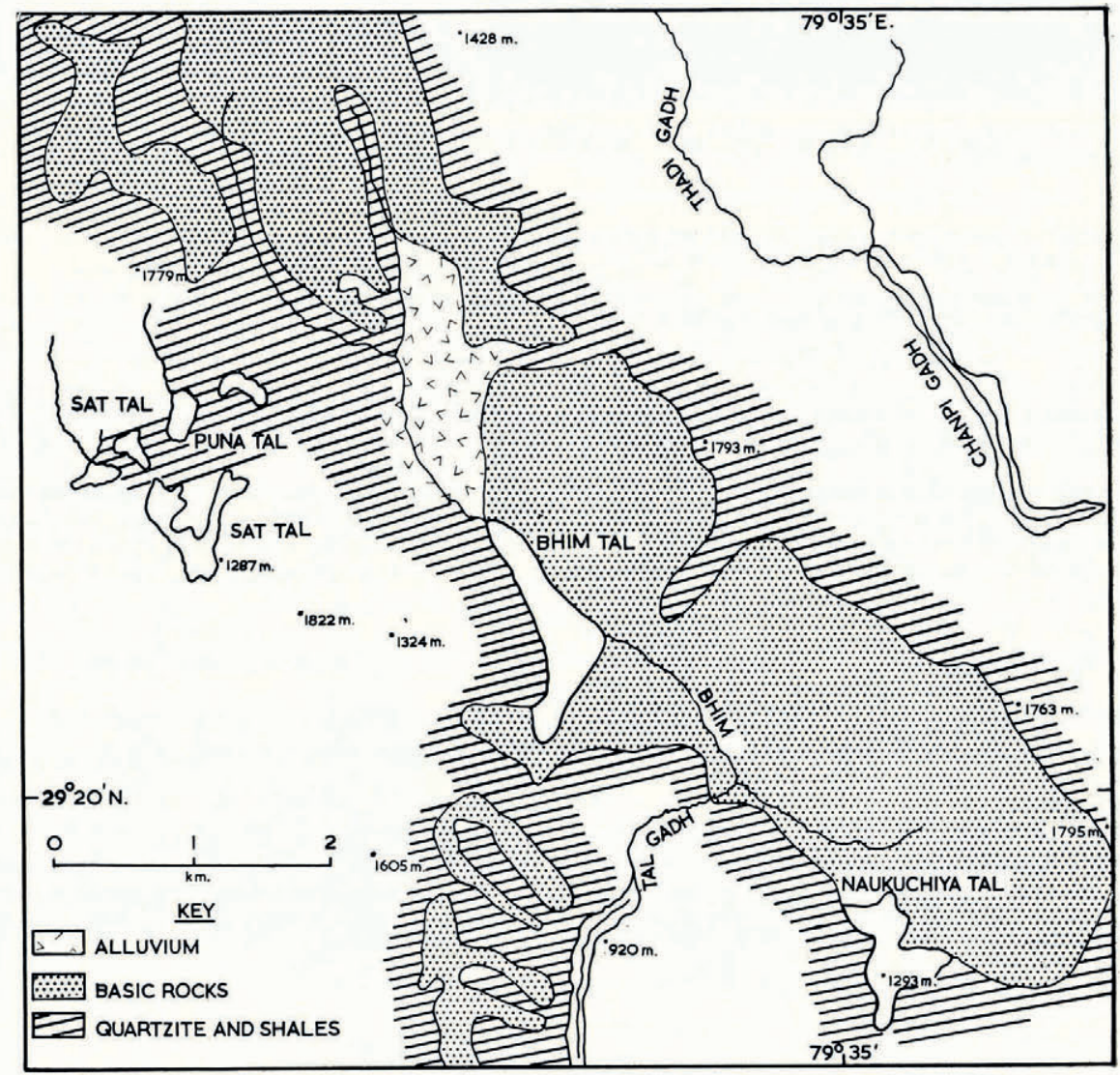

Fig. I. Sketch map of the Kumaon lakes, showing their relationship to the geology of the area

of the ridge. The lake is fed by a small stream which flows from the north-west through low hills composed of basic rocks. The alluvial plain extends towards the north and the water level of this lake is $1,325 \mathrm{~m}$. above sea-level. According to Ball (1878) the length, breadth and depth of the lake are I,702, 453 and $149 \mathrm{~m}$., respectively. In the south the lake is dammed by consolidated debris containing basic rocks and quartzites. Due south of this barrier there is a deep ravine which drains the water from the lake.

\section{Naukuchiya Tal}

Naukuchiya Tal is situated about $4 \mathrm{~km}$. south-east of Bhim Tal and is bounded by low hills to the north. This lake has nine irregular promontories projecting on all sides and looks like a hollow cut out of the mountain slope. It is probably the deepest lake of the area with a length of $95^{2} \mathrm{~m}$., breadth of $63 \mathrm{I} \mathrm{m}$. and depth of about $4 \mathrm{I} \mathrm{m}$. The water level of the lake is $\mathrm{I}, 293 \mathrm{~m}$. above sea-level. The area south-west of the lake is composed of basalts and dolerites and the other hills are massive quartzites.

\section{Sat Tal}

The main lake is $3.25 \mathrm{~km}$. north-west of Bhim Tal and it has a characteristic V-shape in plan. Its two limbs are about $610 \mathrm{~m}$. apart. This lake is surrounded by high and steep hills 
composed of quartzites and schists. Its water level is $1,287 \mathrm{~m}$. above sea-level, and it is about I9 m. deep.

\section{Discussion and Conclusion}

From the earliest times divergent views have been expressed about the origin of these lakes. It therefore seems worthwhile to review earlier ideas before reaching a positive conclusion.

Strachey (185I) believed that the formation of these lakes was associated with an outburst of amygdaloidal trap, but Blanford (1877) attributed a glacial origin to them. Ball (1878) contradicted Blanford's views and suggested denudation and landslip phenomena as being responsible for their origin. Theobald (I880) categorically rejected Ball's suggestion and supported Blanford's views.

A close examination of the geological structure of this area reveals that these lakes are situated in tightly folded hills having steep anticlines and synclines and that they appear to be structural hollows in the mountains. Bhim Tal is surrounded by basalts and dolerites on the east and quartzites on the west. It appears that erosion of this area was due to a fluvioglacial stream, which cut deeply into the rocks. The hill due south of this lake is composed of the material brought down by the glacier, i.e. quartzites, basalt and dolerite. Thus the passage of the glacier was arrested by this barrier and its melt waters gave rise to this lake. Also, the head of the Bhim Tal valley terminates in a cirque-like hollow, the mouth of which is blocked by consolidated material composed of fragments of basalt, dolerite and quartzite. At nearby localities moraine-like material is encountered, but this is rarely recognizable because of weathering and erosion, and it is generally confused with scree material. Although the valley is not typically U-shaped, nor are there any roches moutonnées, it cannot be confused with the V-shape some authors have attempted to establish.

Naukuchiya Tal was also formed by small mountain glaciers. The basalts and dolerites which occur on the north-castern side of the lake served as a barrier to the inland glacier; at first it could only cut small hollows which gradually became deeper and finally filled with melt water to become a lake. The irregular projections along the shoreline of this lake and the characteristic hollow suggest the appearance of a cirque.

The Sat Tal lakes also have a very small outlet and are situated in deeply dissected quartzitic country rock with high hills on all sides. The valley is typically glacial, having two prongs projecting northwards.

In the light of these observations, it may be concluded that the Kumaon lakes have resulted from the melting glaciers which descended to this level. The consolidated material, which blocks the outlets of the lakes was deposited by fluvio-glacial streams flowing from the snouts of the melting glaciers. It is possible that other structural and denudational features might have augmented this activity, but the glaciers and fluvio-glacial streams played a major rôle in shaping the topography of this area. The absence of roches moutonnées and boulder beds in this area has confused observers, but they cannot be expected in every area that has suffered glaciation.

\section{MS. received I April 1.963 and in revised form 30 July 1963}

\section{REFERENCES}

Ball, V. 1878. On the origin of Kumaon lakes. Records of the Geological Survey of India, Vol. 1 1, Pt. 2, p. I 74-82. Blanford, H. F. 1877. [Remarks on Himalayan glaciation.] (In Campbell, J. F. On Himálayan glaciation. [Abstract.] Proceedings of the Asiatic Society of Bengal, January 1877, p. 3-4.)

Heim, A., and Gansser, A. 1939. Central Himalayas: geological observations of the Swiss expedition, 1936. Denkschriften der Schweizerischen Naturforschenden Gesellschaft, Bd. 73, Lief. I.

Strachey, R. 1851. On the geology of part of the Himalaya mountains and Tibet. Quarterly Journal of the Geological Society of London, Vol. 7, Pt. I, p. 292-3io.

Theobald, W. I88o. The Kumaon lakes. Records of the Geological Survey of India, Vol. 13, Pt. 3, p. I6 I-75. 